\title{
Pollution assessment in the Keiskamma River and in the impoundment downstream
}

\author{
OS Fatoki ${ }^{1 *}, \mathrm{P}$ Gogwana ${ }^{2}$ and AO Ogunfowokan ${ }^{3}$ \\ ${ }^{1}$ Research and Development Office, University of Venda for Science and Technology, Thohoyandou 0950, South Africa \\ ${ }^{2}$ Department of Chemistry, University of Fort Hare, Alice 5700, South Africa \\ ${ }^{3}$ Department of Chemistry, Obafemi Awolowo University, Ile-Ife, Nigeria
}

\begin{abstract}
The Keiskamma River and the impoundment, downstream were characterised over a one-year period by using standard physicochemical methods to assess their present qualities. The $\mathrm{pH}$ levels are normal in the river and in the impoundment but turbidity values and the levels of electrical conductivity are high in both water systems. Also, the nutrient levels in both systems are eutrophic. The $\mathrm{DO}$ and BOD levels exceeded EU guideline values for the protection of the aquatic ecosystem. The Keiskammahoek Sewage Treatment Plant (KSTP) was identified as a pollution point source into the receiving river and the impoundment. Its treatment performance was investigated. Significant pollution of the river and the impoundment from the KSTP was indicated for electrical conductivity, nutrients and oxygen-demanding substances.
\end{abstract}

Keywords: Pollution point source, river impoundment

\section{Introduction}

South Africa's water resources have been under increasing threat of pollution in recent years due to rapid demographic changes, which have coincided with the establishment of human settlements lacking appropriate sanitary infrastructure. This applies especially to peri-urban areas, which surround the larger metropolitan towns in the country. Many such settlements have developed with no proper water supply and sanitation services. People living in these areas, as well as downstream users, often utilise the contaminated surface water for drinking, recreation and irrigation, which creates a situation that, poses a serious health risk to the people (Verma and Srivastava, 1990). Such is the case in the town of Keiskammahoek, the Eastern Cape that has inadequate water-borne sanitation.

The domestic water supply of the community comes from the Keiskamma River, which owing to lack of proper sanitation, is continually polluted. Problems experienced in the Transitional Local Council (TLC) with sewage discharges into the river escalated when RDP-housing units were connected to the Keiskammahoek Sewage Treatment Plant (KSTP) in 1997 without any expansion/upgrading reticulation system. Bypassing due to overflows has occurred regularly since then. The treatment works were built as an anaerobic/aerobic pond system, which means that the treatment occurs naturally without added chemicals. The problem of too high an inflow load results in a poor level of sewage purification and, as a result, pollution of the receiving Keiskamma River.

The community of Keiskammahoek uses the water from the Keiskamma River for a variety of purposes such as drinking, fishing, livestock watering and recreational purposes. The Sandile Dam is situated downstream of the town on Keiskamma River. Water from this dam is treated to supply the whole of Keiskammahoek Transitional Local Council (TLC) and the Middledrift

\footnotetext{
* To whom all correspondence should be addressed.

政+27 40 602-2094; fax: +27 4060 22094; e-mail: OFatoki@ufh.ac.za Received 1 July 2002; accepted in revised form 7 March 2003.
}

District. Although it is possible to renovate polluted surface waters to potable standard, the process required would be both complex and very expensive (DWAF, 1998), which may make the supply unsustainable. Moreover, several communities use water from the Keiskamma River for domestic purposes without prior treatment and it is therefore of great importance that the river remains in a "healthy" state. However, fears have been raised that due to the potential discharges from the KSTP, the river could be excessively polluted. Our initial study on the KSTP and the impact of its effluents on the receiving Keiskamma River in 1999 (Morrison et. al., 2001) indicated gross pollution of the river by effluents from the sewage plant. Then recommendation was given on the need for an upgrade of the sewage plant to improve the quality of its effluents. Recently, two major modifications were made on the KSTP: a central pump station was built for the town's sewer system and an aeration pump was installed into the pond system. However, it is doubtful if these modifications would be enough to improve the quality of its effluent discharges and to reduce its impact on the river. This study focuses on the present water quality of the Keiskamma River and the impoundment, downstream (i.e. Sandile Dam) and on the quality of the effluent discharges from the KSTP after the recent modifications.

\section{Materials and methods}

\section{Sampling sites}

The location of the sampling points in the Keiskamma River, the impoundment and the KSTP is shown in Fig 1. Effluent samples were taken from the KSTP at Site S1. Site S2 was the sampling point from the river while Site $\mathrm{S} 3$ was the sampling point from the impoundment (i.e. Sandile Dam). Both Sites S2 and S3 were downstream of the sewage discharge point.

Before sampling for chemical analysis, sample bottles were cleaned by soaking in detergent for $24 \mathrm{~h}$, followed by rinsing several times with tap water until free of detergent, rinsed with 5\% nitric acid and then thoroughly with distilled-deionised water (DWAF, 1992; DWAF, 1999). 


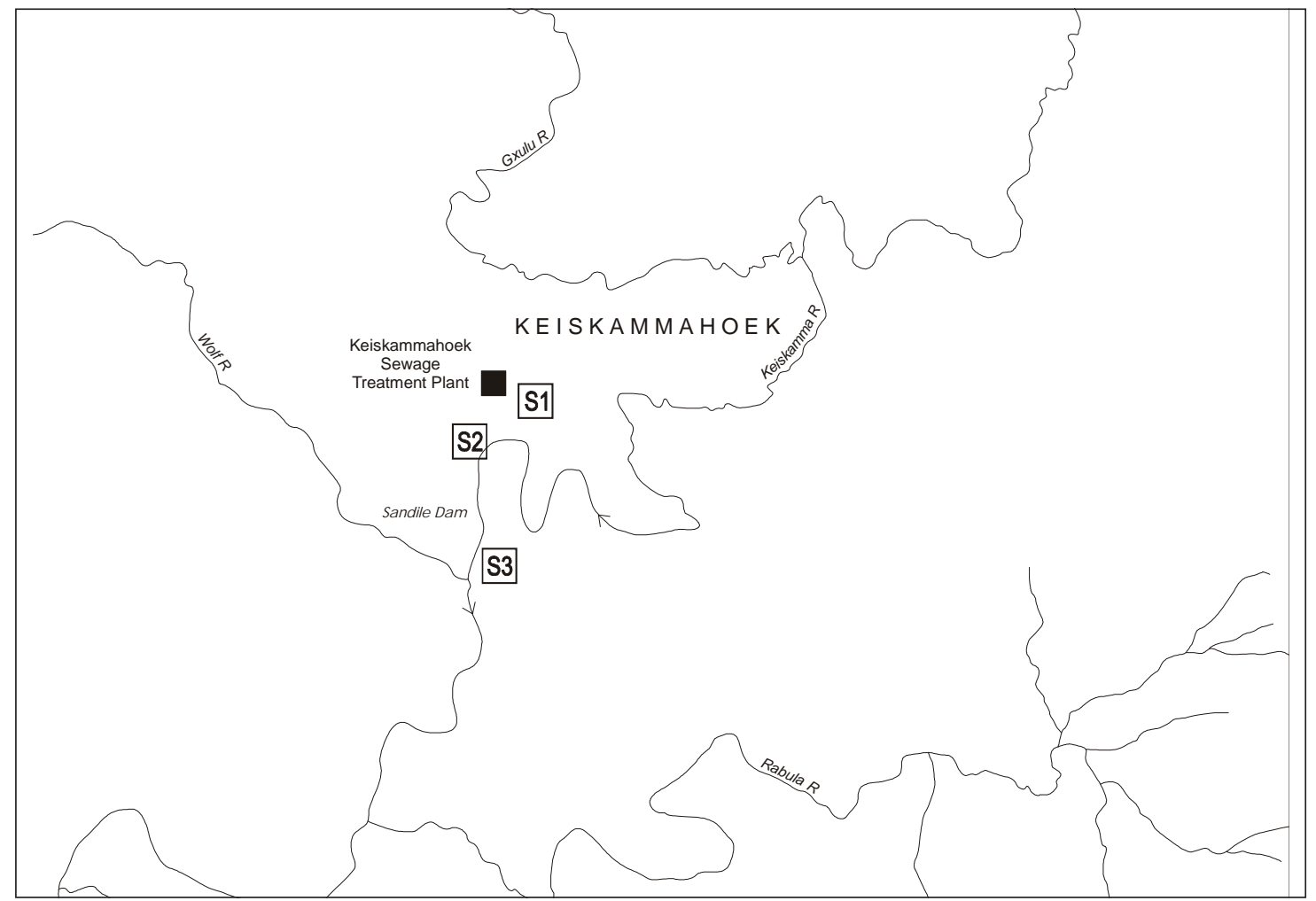

Figure 1

Map of the sampling site

Samples for the chemical analyses were collected according to the standard procedures described in the sampling guide (DWAF, 1992; DWAF, 1999). Samples were analysed within $24 \mathrm{~h}$. Sampling was done on 26th June, 19th July, 22nd August, 4th October, 17th November and 30th November 2000 and on 7th February, 20th March, 9th May and 30th May 2001, respectively.

\section{Physico-chemical analyses}

Temperature and $\mathrm{pH}$ were determined on-site with a $\mathrm{pH} 330$ meter supplied by Merck NT Laboratory Pty Ltd. Electrical conductivity (EC) was determined with the LF 330 conductivity meter also supplied by Merck NT Pty Ltd. Turbidity was determined using the HI 93703 microprocessor turbidity meter (Hanna Instruments). Nitrate, orthophosphate as P, chlorides, sulphates and chemical oxygen demand (COD) were determined by the standard photometric method (DWAF, 1992) using the Spectroquant Nova 60 Photometer supplied by Merck NT PTY Ltd. Samples for COD analyses were digested with Merck Thermo reactor Model TR 300 and then analysed by the Merck Nova 60 photometer. Dissolved oxygen (DO) was measured with the Merck DO meter, Model Oxi 330 supplied by Merck PTY. Biochemical oxygen demand $\left(\mathrm{BOD}_{5}\right)$ was determined using the Oxitop WTW BOD meter supplied by Merck Pty Ltd. The incubation period for BOD determinations was $5 \mathrm{~d}$. Being a non-industrial area, heavy metals were not considered a possible problem in the river or in the effluent discharges and therefore were omitted from this study.

\section{Results and discusssion}

\section{Quality parameters in the Keiskamma River and the impoundment}

The results of the one-year measurement campaign for the river and the impoundment downstream are shown in Figs. 2 to 5.
The mean $\mathrm{pH}$ value in the river water was 6.9 and the mean $\mathrm{pH}$ value in the impoundment was 7.1 (Fig. 2). The SA target water quality range for $\mathrm{pH}$ in water for domestic use (DWAF, 1996a) is 6 to 9 and the target water quality range for $\mathrm{pH}$ in water for full contact recreational use (DWAF, 1996b) is 6.5 to 8.5. The EU also sets protection limits of 6 to 9 for fisheries and aquatic life (Chapman, 1996). The $\mathrm{pH}$ obtained in the river fell within these ranges. Based on these guidelines, the $\mathrm{pH}$ of the river water and the impoundment would not adversely affect its use for domestic uses, recreational and the aquatic ecosystem purposes.

Electrical conductivity values varied between $152.0 \mathrm{mS} / \mathrm{m}$ and $350.0 \mathrm{mS} / \mathrm{m}$ (mean value, $263.9 \mathrm{mS} / \mathrm{m}$ ) in the Keiskamma River and between $115 \mathrm{mS} / \mathrm{m}$ and $240 \mathrm{mS} / \mathrm{m}$ (mean value, $164.9 \mathrm{mS} / \mathrm{m}$ ) in the dam (Fig. 2). The South African acceptable limit for conductivity in domestic water supply is $70 \mathrm{mS} / \mathrm{m}$ (DWAF, 1996a). This limit was exceeded in the river water and in the dam. Therefore the parameter does give concern and it would make the water unsuitable for direct domestic use. The source of high conductivity in the river could be from effluent discharge from the KSTP. The levels of EC reported in this study for Keiskamma River were much higher than those reported for the Isinuka Springs (Faniran et al., 2001).

Turbidity values ranged from 14.9 to $90.0 \mathrm{NTU}$ (average, 28.7 NTU) in river water samples and varied between 7.2 NTU and 99.0 NTU (average, 44.2 NTU) in the impoundment (Fig. 2). The South African Target Water Quality Range (DWAF, 1996a) for turbidity in water for domestic water supply is 0 to 1 NTU. These values are grossly exceeded in the water samples and it disqualifies the river for direct domestic use. Also, the excessive turbidity in water can cause problems with water purification processes such as flocculation and filtration, which may increase treatment cost (DWAF, 1998). There also may be a tendency for an increase in trihalomethane (THM) precursors, where highly turbid waters are chlorinated. Elevated turbid waters are often associated with the possibility of microbiological contamination, as high turbidity makes it difficult 
to disinfect water properly (DWAF, 1998). The high turbidity also makes the sight of the river water unpleasant for full-contact recreation (DWAF, 1996b).

The levels of turbidity recorded in this study were much higher than those reported for Isinuka River (spring average, 43.03 NTU and summer average, 0.6 NTU) by Faniran et al. (2001). Soil erosion and runoff from the rural catchment could be the source of high turbidity in the water systems.

\section{Nutrients}

Nutrient levels are indicated in Fig. 3. Nitrate levels averaged $2.2 \mathrm{mg} / \mathrm{l}$ as $\mathrm{N}$ in the river and $1.9 \mathrm{mg} / \mathrm{l}$ as $\mathrm{N}$ in Sandile Dam. The South African guideline for nitrate in domestic water is $6 \mathrm{mg} / \mathrm{l}$ as N (DWAF, 1998; DWAF, 1996a) and the WHO safe limit for nitrate for lifetime use is $10 \mathrm{mg} / \mathrm{l}$ as N (WHO, 1984). These limits were not exceeded in both water systems; thus nitrate is not considered to pose a problem for the domestic use of water from the river and the impoundment (Bush and Meyer, 1982; Canter, 1987). However, nitrate is a problem for other uses because of eutrophication (DWAF, 1996c; Rast and Thornton, 1996).

Mean levels of phosphate were $0.08 \mathrm{mg} / \mathrm{l}$ as $\mathrm{P}$ in the river and $0.12 \mathrm{mg} / \mathrm{l}$ as $\mathrm{P}$ in the impoundment (Fig. 3). The South African guideline for $\mathrm{P}$ in water systems that will reduce the likelihood of algal and other plant growth is $5 \mu \mathrm{g} / \mathrm{l}$ (DWAF, 1996c). Other workers have reported that eutrophication-related problems in temperate zones of aquatic systems begin to increase at ambient total $\mathrm{P}$ concentrations exceeding $0.035 \mathrm{mg} \mathrm{P} / \mathrm{l}$. The value is higher for warm-water systems - of the order of 0.34 to $0.70 \mathrm{mg} P / \mathrm{l}$ (Rast and Thornton, 1996). The associated $\mathrm{N}$ concentration would be of the order of 0.34 to $0.70 \mathrm{mg} \mathrm{N} / \mathrm{l}$. It is accepted that these represent nutrient threshold levels, beyond which there will be a corresponding increase in the risk and intensity of plant-related water quality problems (OECD, 1982). These limits for nutrients (DWAF, 1996c; Rast and Thornton, 1996) are exceeded in the river and in the impoundment and eutrophication would be a problem in the river and in Sandile Dam.

Water from the Sandile Dam is abstracted and treated to supply water to Keiskammahoek and eutrophication could increase its treatment cost through filter clogging in water treatment works (Murray et. al., 2000). Also, the incidence of eutrophication could adversely affect the use of the river and the dam for recreation purposes as the covering of large areas by macrophytes could prevent access to waterways and could cause unsightly and malodorous scum which could make recreation unpleasant. In addition, the high nutrient values could lead to the growth of blue-green algae, which could release toxic substances (cyanotoxins) into the water systems. Cyanotoxins are recognised to have caused the death of farm livestock (Holdsworth, 1991).

The nitrate levels in Keiskamma River are higher than those reported for Isinuka River by Faniran et al. (2001) (summer average, $0.5 \mathrm{mgNO}_{3}^{-}-\mathrm{N} / \mathrm{l}$ ); however, the water quality situation in Keiskamma River compares favourably with that reported for Buffalo River (Buffalo River catchment unlike Keiskamma River is a designated sensitive catchment) (DWAF, 1988) where nutrient contamination was listed among the variables of concern (WRC, 1996). Urban effluents from the sewage treatment works and diffuse runoff from urban catchments were said to be the source of phosphate in the Buffalo River. The high nutrient levels in the Keiskamma River and in the impoundment may be due to pointsource discharge from the KSTP and to diffuse sources from settlements and agricultural runoff.

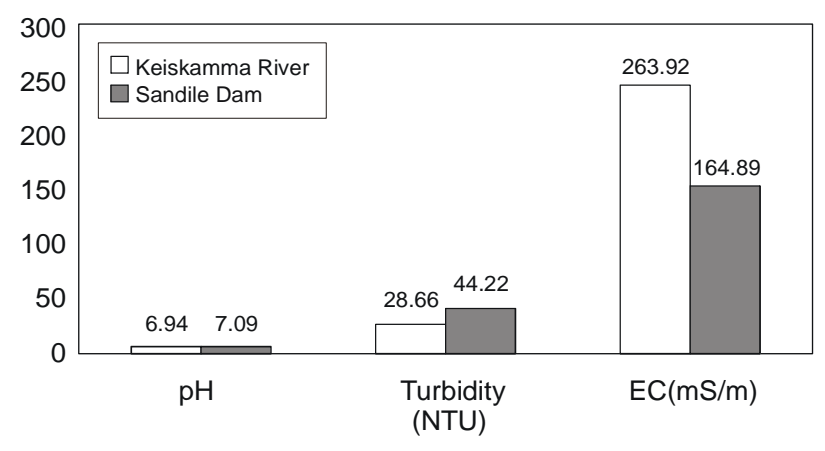

Figure 2

Variations of the mean values of $\mathrm{pH}$ electrical conductivity and turbidity in Keiskamma River (S2) and in Sandile Dam (S3)

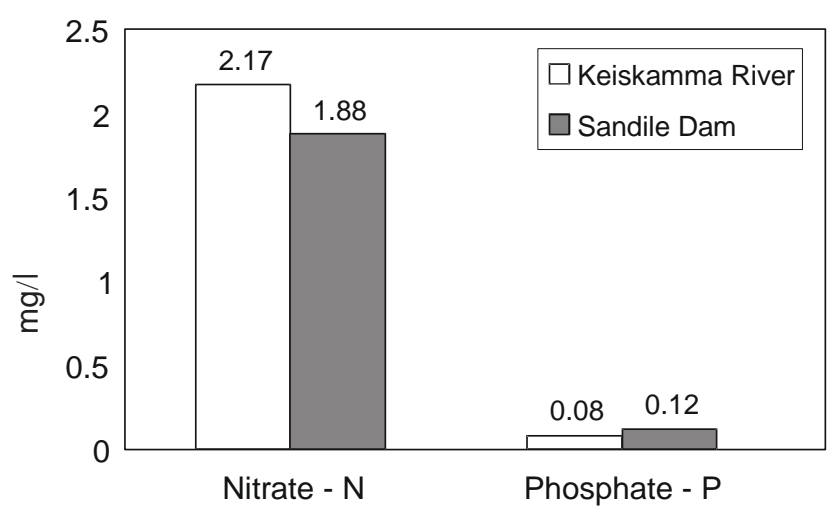

Figure 3

Variations of mean values of the nitrate- $N$ and phosphate- $P$ in Keiskamma River (S2) and in Sandile Dam (S3)

\section{Figure 4}

Variations of the mean values of the chloride and sulphate in Keiskamma River (S2) and in Sandile Dam (S3)

\section{Chloride and sulphate}

The mean chloride value was $25.7 \mathrm{mg} / \mathrm{l}$ in river water $17.7 \mathrm{mg} / \mathrm{l}$ in the impoundment (Fig. 4). The mean sulphate values were also $29.1 \mathrm{mg} / \mathrm{l}$ in the river and $23.2 \mathrm{mg} / \mathrm{l}$ in the impoundment, respec- 


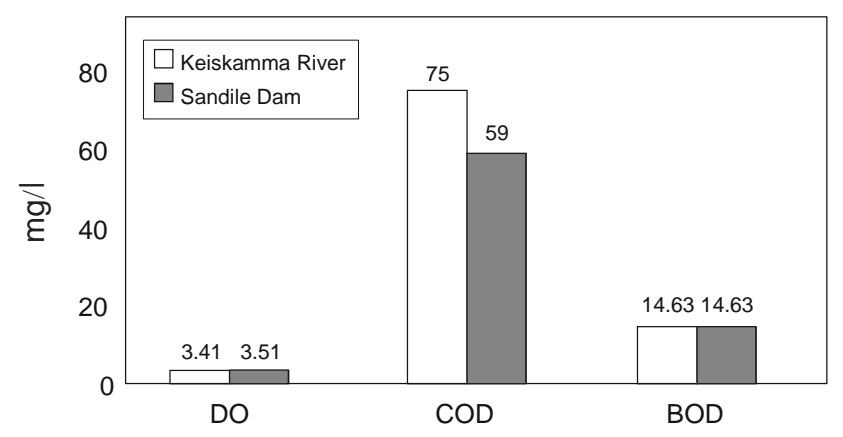

Figure 5

Variations of the mean values of $D O, C O D$ and $B O D$ in Keiskamma River (S2) and in Sandile Dam (S3)

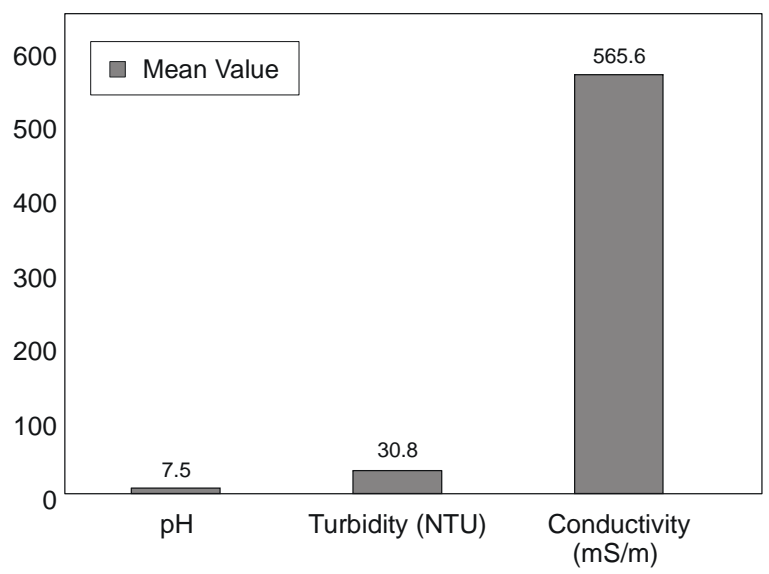

Figure 6

Variation of mean values of $\mathrm{pH}$, turbidity and electrical conductivity in effluent discharges from the KSTP (S1)

tively. The South African guideline for chloride in domestic water supply is $100 \mathrm{mg} / \mathrm{l}$ while the guideline for sulphate is $200 \mathrm{mg} / \mathrm{l}$ (DWAF, 1996a). Based on these guidelines the values of chloride and sulphate in the river and in the impoundment are normal for domestic use.

\section{Oxygen-demanding substances}

The mean levels of oxygen-demanding substances in the river and in the impoundment are shown in Fig. 5. Dissolved oxygen levels (average, 3.4) varied between $2.7 \mathrm{mg} / \mathrm{l}$ and $3.6 \mathrm{mg} / \mathrm{l}$ in the Keiskamma River and ranged from 2.7 to 3.8 in Sandile Dam (average, $3.5 \mathrm{mg} / \mathrm{l}$ ).

Dissolved oxygen is an important element for water quality control. The effect of waste discharge on a river is largely determined by the oxygen balance of the system and its presence is essential to maintain biological life within a system (DFID, 1999). Pristine surface waters are normally saturated with DO, but such DO can be rapidly removed by the oxygen demand of organic wastes and the measurement of DO provides a broad indicator of water quality (DFID, 1999). DO concentrations in unpolluted water are normally about 8 to $10 \mathrm{mg} / \mathrm{l}\left(\right.$ at $25^{\circ} \mathrm{C}$ ) (DFID, 1999). Concentrations below $5 \mathrm{mg} / \mathrm{l}$ adversely affect aquatic life. The concentrations of DO in the river and the impoundment are much less than $5 \mathrm{mg} / \mathrm{l}$ and therefore the river water and the impoundment would not be suitable for use of the aquatic ecosystem.

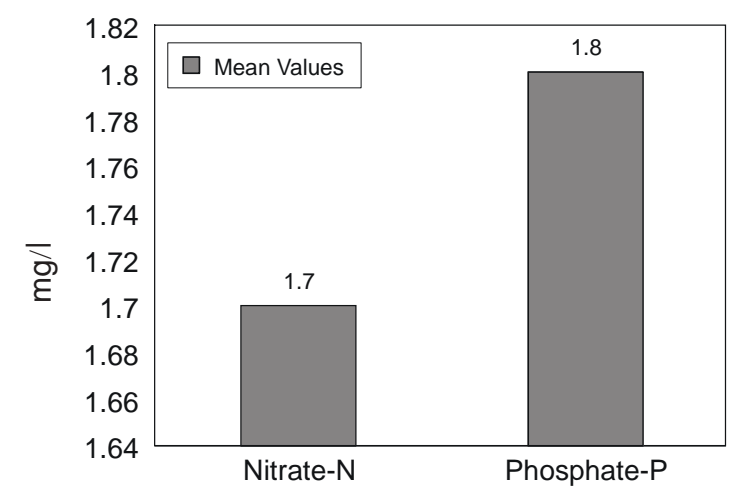

Figure 7

Variation of mean values of nitrate- $N$ and phosphate- $P$ in effluent discharges from the KSTP (S1)

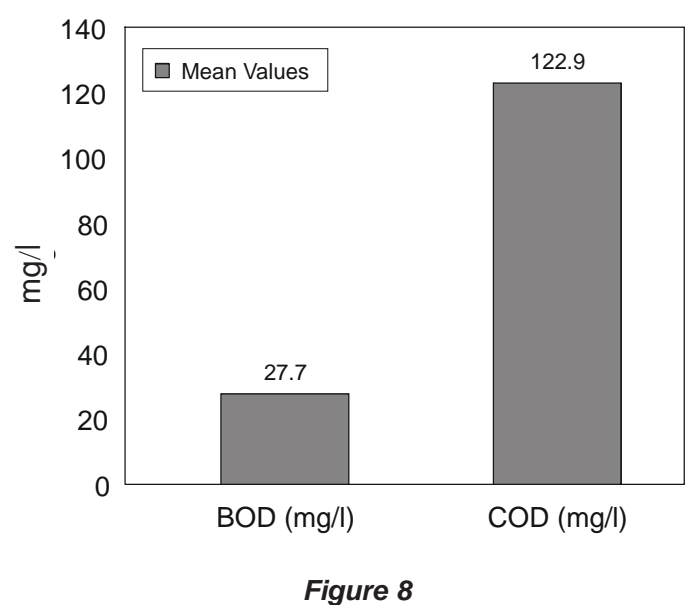

Variation of the mean values of $B O D$ and $C O D$ in effluent discharges from the KSTP (S1)

The mean BOD levels in the river and in the impoundment were $14.6 \mathrm{mg} / \mathrm{l}$ each. The BOD shows how much oxygen is needed by the water to completely oxidise its organic pollution load. The BOD levels recorded in the river water and in the impoundment are much higher than the EU guidelines of 3.0 to $6.0 \mathrm{mg} / \mathrm{l}$ for the protection of fisheries and the aquatic life (Chapman, 1996). The high level of BOD in the river and in the impoundment also disqualifies the water systems for the use of the aquatic ecosystem.

The mean COD value in the river water samples was 75.0 $\mathrm{mg} / \mathrm{l}$ while the mean level in the impoundment was $59 \mathrm{mg} / \mathrm{l}$. Though there are no COD guidelines in the new South African Water Quality Guidelines, the oxygen-free water entering the Sandile Dam, downstream would have negative effects on the freshwater quality as well as cause harm to the aquatic life in the dam with potentially dire consequences on the biota (e.g. fish).

\section{Quality of effluent discharges from the KSTP}

The effluent from the KSTP has always been suspected as a significant pollution point source into the Keiskamma River. The results of the one-year measurement campaign for effluent discharges from the Keiskammhoek Sewage Treatment plant after its recent modifications are shown in Figs. 6 to 8 .

Mean $\mathrm{pH}$ value in the effluent is 7.5 (Fig. 6). The old SA guidelines for $\mathrm{pH}$ in effluents that will be discharged into the river are in the range of 5.5 to 7.5 (Government Gazette, 1984). This 
limit was not exceeded in the effluent. There are neither major industries nor mining activities in the area that could cause extreme changes in the $\mathrm{pH}$ of the effluents and of the receiving river, therefore the results obtained for $\mathrm{pH}$ in this study were as expected.

The old SA guideline for EC in effluent that will be discharged into the river is $250 \mathrm{mS} / \mathrm{m}$ (Government Gazette, 1984). The mean EC value in effluent was $565.6 \mathrm{mS} / \mathrm{m}$ (Fig. 6). Based on this guideline value for effluents there is no compliance with the regulation for electrical conductivity in effluent.

Turbidity values in effluents (Fig. 6) ranged from 7.0 to 127.0 NTU (average, $30.8 \mathrm{NTU}$ ) but there is no SA guideline for turbidity in effluent discharge (Government Gazette, 1984).

The mean nitrate value in effluents was $1.7 \mathrm{mg} / \mathrm{l}$ as $\mathrm{N}$ (Fig. 7). The old South African guideline for nitrate in sewage effluents is $1.5 \mathrm{mg} / \mathrm{I} \mathrm{NO}_{3}^{-}$as N (Government Gazette, 1984). This guideline was also exceeded in the effluent samples.

The levels of phosphate in effluent varied between $0.7 \mathrm{mg} \mathrm{PO}_{4}^{3-}$ as $\mathrm{P} / \mathrm{l}$ and $3.1 \mathrm{mg} \mathrm{PO}_{4}^{3-}$ as $\mathrm{P} / \mathrm{l}$ (mean value, $1.8 \mathrm{mg} / \mathrm{PO}_{4}^{3-}$ as $\mathrm{P}$ ) (Fig. 7). The Keiskamma River Catchment is a non-sensitive catchment (DWAF, 1988). The South African special standard for phosphate in effluent in non-sensitive catchments is $1 \mathrm{mg} / / \mathrm{PO}_{4}^{3-}$ as P (Government Gazette, 1984; DWAF, 1988). The mean phosphate level in the effluent exceeded this standard and this would indicate that the KSTP is a major point-source of nutrient to the river catchment.

The mean COD and BOD levels in effluents were $122.9 \mathrm{mg} / \mathrm{l}$ and $27.7 \mathrm{mg} / \mathrm{l}$, respectively (Fig. 8). The old South African guideline for COD in effluents that are allowed to be discharged into the river is $30 \mathrm{mg} / \mathrm{l}$ (there was no guideline for BOD in effluent) (Government Gazette, 1984). The COD values in effluents were almost four times higher than the acceptable limit. This indicates the inefficiency of the treatment plant in removing the chemical oxygen-demanding substances in the influent.

The KSTP is still in a "shambolic state" and seems to do very little in the way of "treatment". Significant pollution of the river and the impoundment (i.e. Sandile Dam) was indicated for EC, orthophosphate and oxygen-demanding substances due to the point source, despite its recent modifications. This inefficiency of the treatment plant should be given urgent attention by the water authorities because people's health and the ecosystem health are at stake.

\section{Conclusion}

The levels of EC, nitrate, orthophosphate and oxygen-demanding substances were above the SA guideline values in both the Keiskamma River and in Sandile Dam. The KSTP does not comply with the SA effluent regulations for these parameters and is a significant point source of pollution into the river and the Dam. The KSTP needs further upgrading to improve its treatment performance to ensure sustainable use of the water for the downstream users.

\section{Acknowledgement}

We thank the NRF for funding this research study.

\section{References}

BUSH D and MEYER M (1982) A case of infantile methemoglobinemia in South Dakota. J. Environ. Health 44 310-311.

CANTER LW (1987) Nitrate and pesticides in ground water: An analysis of a computer-based literature search. In: Fairchild-Lewis DM (ed.) Ground Water Quantity and Agricultural Practices. Chelsea, MI.

CHAPMAN D (1996) Water Quality Assessments (2nd edn.). Publ. E \& FN Spon, London.

DFID (1999) A Simple Methodology for Water Quality Monitoring. Pearce GR, Chaudhry MR and Ghulum S (eds.), Department for International Development, Wallingford.

DWAF (1988) Important Announcement on Implementation of the Special Phosphate Standard in Sensitive Catchments. IMIESA (Johannesburg), 13 (9) 35.

DWAF (1992) Analytical Methods Manual, TR 151. Department of Water Affairs \& Forestry, Pretoria.

DWAF (1996a) South African Water Quality Guidelines (Volume 1), Domestic Uses (2nd edn.). Department of Water Affairs \& Forestry, Pretoria.

DWAF (1996b) South African Water Quality Guidelines, (Volume 2), Recreational Water Use (2nd edn.). Department of Water Affairs \& Forestry, Pretoria.

DWAF (1996c) South African Water Quality Guidelines (Volume 7), Aquatic Ecosystems (1st edn.). Department of Water Affairs \& Forestry, Pretoria.

DWAF (1998) Quality of Domestic Water Supplies. Assessment Guide. 1 (2nd edn.) Department of Water Affairs \& Forestry, Department of Health and Water Research Commission.

DWAF (1999) Quality of Domestic Water Supplies. Sampling Guide 2. Department of Water Affairs \& Forestry, Department of Health and Water Research Commission.

FANIRAN JA, NGCEBA FS, BHAT RB and OCHE CY (2001) An assessment of the water quality of the Isinuka springs in the Transkei region of Eastern Cape, Republic of South Africa. Water SA 27 (2) 241-250.

GOVERNMENT GAZETTE (1984) Requirements for the Purification of Wastewater or Effluent. Gazette No 9225, Regulation No 991, 18 May.

HOLDSWORTH R (ed.) (1991) New Health Consideration in Water Treatment. Avebury Technical, Aldershot.

MORRISON G, FATOKI OS, PERSSON L and EKBERG A (2001) Assessment of the impact of point source pollution from the Keiskammahoek Sewage Treatment Plant on the Keiskamma River $\mathrm{pH}$, electrical conductivity, oxygen-demanding substance (COD) and nutrients. Water SA 27 (4) 475-480.

MURRAY K, DU PREEZ M and VAN GINKEL C (2000) National Eutrophication Monitoring Programme. Implementation Manual Draft. Water Research Commission, Pretoria.

OECD (1982) Eutrophication of Waters: Monitoring, Assessment and Control. Technical report. Organisation for Economic Development, Paris.

RAST W and THORNTON JA (1996) Trends in eutrophication research and control. Hydrol. Process 10295.

WHO (1984) Guidelines for Drinking Water Quality. World Health Organization, Geneva

WRC (1996) A Situation Analysis of Water Quality in the Catchment of the Buffalo River, Eastern Cape, with Special Emphasis on the Impacts of Low Cost, High-Density Urban Development on Water Quality. O'Keeffe JH, Van Ginkel CE, Hughes DA, Hill TR and Aston PJ (eds.) WRC Report No. 405/1/96.

VERMA BL and SRIVASTAVA RN (1990) Measurement of the personal cost of illness due to some major water-related issues in an Indian rural population. Int. J. Epidemiol. 19 169-176. 


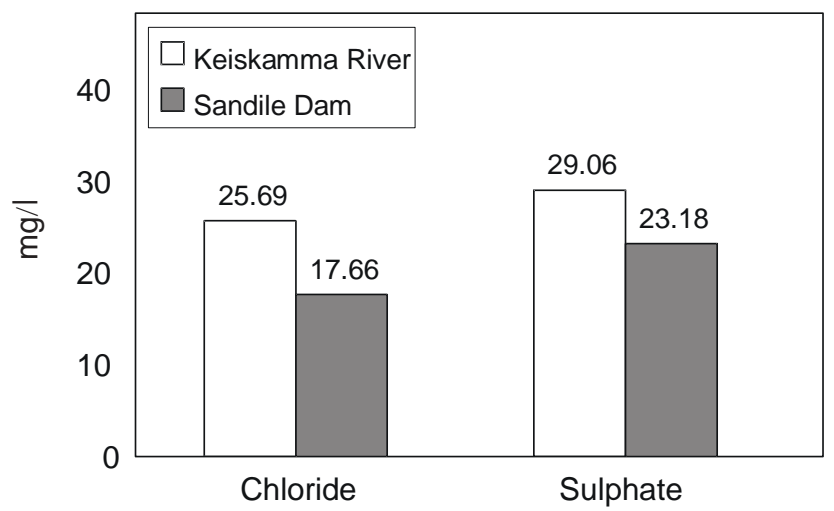

Figure 4 